\title{
EFEKTIVITAS KOMBINASI EKSTRAK JAHE DAN PIRIDOKSIN UNTUK MENGURANGI MUAL MUNTAH IBU HAMIL
}

\author{
Hesti Kurniasih, Fitria Zuhriyatun, Siti Nur Faizah \\ Poltekkes Kemenkes Semarang \\ hestikurnaisih27@gmail.com
}

\begin{abstract}
Nausea vomiting is one of the most common complaints experienced by pregnant women in the first 3 months, the condition can be a serious condition that is hyperemesis gravidarum which results in disrupting the welfare of the mother and fetus, the essential content of ginger to overcome nausea and vomiting. This study aims to assess the effectiveness of a combination of ginger extract and pyridoxine in reducing complaints of nausea and vomiting in pregnant women under 3 months. A quasi- experimental, prospective randomized controlled study method involving pregnant women with a gestational age of $\leq 11$ weeks in the working area of Puskesmas 1 \& 2 Baturraden. The treatment group received a combination of $200 \mathrm{mg}$ of ginger extract given 3 times daily + pyridoxine $15 \mathrm{mg}$ once daily for 7 days while the control group received pyridoxine $1 \times 25 \mathrm{mg}$ per day for 7 days. Complaints of nausea and vomiting were measured using the Rhodes Index. After 7 days of data processing, the significance value of the chi-square test $p$ value was 0,000 and the chi-square value of 41,060> 3,841. Because the significance value of $0.000<(0.05)$ or the calculated chi square value of $41.060>$ 3.841 means that there is a relationship between the treatment of ginger extract and pyridoxine turns out to be significantly more significant in reducing complaints of nausea and vomiting of pregnant women compared to pyridoxine alone.
\end{abstract}

Keywords: ginger extrac ; pyridoxine ;nausea vomitin ; pregnancy

\begin{abstract}
ABSTRAK
Nausea vomiting is one of the most common complaints experienced by pregnant women in the first 3 months, the condition can be a serious condition that is hyperemesis gravidarum which results in disrupting the welfare of the mother and fetus, the essential content of ginger to overcome nausea and vomiting. This study aims to assess the reduction in nausea and vomiting using a combination of ginger extract and pyridoxine. A quasi-experimental, prospective randomized controlled study method involving pregnant women with a gestational age of $\leq 11$ weeks in the working area of Puskesmas $1 \& 2$ Baturraden. The treatment group received a combination of $200 \mathrm{mg}$ of ginger extract given 3 times daily pyridoxine $15 \mathrm{mg} 1 \times$ daily for 7 days while the control group received pyridoxine $1 \times 25 \mathrm{mg}$ per day for 7 days. Measuring the scale of nausea and vomiting using the Rhodes Index. After 7 days of data processing, the significance value of the chi-square test $p$-value of 0,000 and the value of chi-square of $41,060>3,841$. Because the significance value of $0.000<(0.05)$ or the calculated chi square value of $41.060>3.841$ means that the administration of a combination of ginger extract and pyridoxine is significantly more significant in reducing nausea and vomiting in pregnant women compared to administration of pyridoxine alone
\end{abstract}

Kata Kunci: Ekstrak jahe ; piridoksin ; mual muntah ;kehamilan 


\section{Pendahuluan}

Mual muntah pada ibu hamil dapat menimbulkan gangguan aktifitas sehari-hari pada kasus tertentu akan menimbulkan bahaya baik ibu maupun janin. komplikasi yang memungkinkan terjadi adalah kematain ibu maupun bayi pada kasis hiperemesis gravidarum. Jika dibiarkan berakibat menghambat pertumbuhan janin, kelainan congenital bahkan pada kasus tertentu dapat mengakibatkan kematian janin dalam kandungan. Komplikasi pada ibu bisa mengakibatkan dehidrasi, gangguan keseimbangan asam basa, dan kekurangan kalium. Gejala mual dan muntah pada ibu hamil biasanya terjadi pada trimester satu dan bias berlanjut selama kehamilan.

Menurut, Smit et al (2004) ibu hamil membutuhkan istirahat dari pekerjaannya ketika mengalami mual muntah. Mual dan muntah merupakan gejala yang mungkin dan sering kedapatan pada kehamilan trimester pertama. Mual muntah terjadi pada agi ahri bias berlanjut hingga malam hari . Gejala ini muncul 6 minggu setelah HPHT sampai 10 minggu. Kejadian ini akan lebih berat pada satu dari seribu kehamilan.

Pada beberapa kasus mual muntah dapat ditangani menggunakan obat. Akan tetapi pada beberapa kasus ibu hamil tidak dapat mengatasi hingga terjadi kekurangan elektrolit. Penurunan kalium akibat berkurangnya elektrolit akan mengakibatkan pengentalan darah yang dengan begitu akan memperberat mual muntah. Pada masyarakat belum ada pengobatan menggunakan ekstrak jahe yang dilakukan penelitian, dengan pemberian ekstrak jahe dapat merangsang kontrol terhadap mual muntah sehingga dapat mengalihkan mual muntah.

Jahe merupakan jenis tanaman herbal yang memiliki keunggulan lebih dbandingkan dengan tanaman sejenis yang lain, terutama bagi ibu hamil yang mengalami mual muntah. Keunggulan utama jahe adalah akndungan minyak atsiri yang mengahsilkan aroma segar dan memiliki efek dapat memblokir reflek munta, keutamaan kedua yaitu gingerol melancarkan peredaran darah sehingga syaraf dapat bekerja dengan baik. Pada akhirnya ketegangan dapat dihilangkan dan pikiran menjadi segar sehingga mual muntah dpat ditekan .
Prof. Caroline Smith mengatakan bahwa jahe memiliki efek untuk mengendurkan otototot pada saluran pencernaan sehingga menurunkan frekuensi mual muntah. Penelitian ini dilakukan perlakuan pada ibu hamil dengan mual dan muntah dengan pemberian $10 \mathrm{mg}$ ekstrak jahe, ternyata hasilnya sangat signifikan terjadi penurunan frekuensi mual muntah pada ibu hamil.

Ekstrak jahe telah dikenal di wilayah Asia untuk mengurangi mual muntah sejak abada ke 15. Pada penelitian tersebut didapatkan ekstrak jah lebih dominan mengurangi mual muntah dibandngkan placebo. Pengobatan tradisional Cina tidak menyarankan pemberian ekstrak jahe dikarenakan kurangnya bukti-bukti penelitain. Sementara penelitian pada tikus, uci coba yang dilakukan menyebabkan kematian janin dan pertumbuhan yang kecil. Ulasan Sistematik Cochrane juga memperlihatkan bahwa piridoksin hanya efektik mengurangi mual muntah tetapi tidak mengurangi frekuensi muntah.

Penelitian ini bertujuan untuk melihat apakah ekstrak jahe lebih efetif menurunkan mual muntah dan sebagai pembanding kami menggunakan piridoksin saja.

Tinjauan Pustaka

Etiologi mual dan muntah (emesis gravidarum) pada kehamilan

Kehamilan awal biasanya terjadi mual dan muntah utamanya pagi hari. Pada aksus tertentu akan hilang pada usia kehamilan 16 minggu tetapi ada sebagian kecil yang menetap selama kehamilan.. pada ibu hamil dengan kondisi mua muntah ringan dapat diobat, akan tetapi pada kasus sedang biasanya membutuhkan waktu untuk istirahat dari pekerjaanya. Menurut Golbert (2006) ibu hamil yang mengalami mual muntahs edang membutuhkan waktu istirahat dari pekrjaanya.

Penyebab Mual dan Muntah

Lacasse et al, 2009, yang mengatakan bahwa penyebab mula muntah adalah multifaktor. Menurut Wedro (2009) selain karena factor kehamilan sendiri juga ada factor penyakit lain yaitu gastritis akut, penyebab syaraf, penyakit lambung yang lain, ataupun factor obat medis, dan obstruksi saluran cerna.

Pengukuran Mual dan Muntah

Pengukuran frekuensi mual muntah dapat dilakukan dengan metode sederhana yaitu pertanya dengan jawaban ya atau tidak, atau 
bias dilakukan dengan penlian dengan rentang 4 skor.

Jarak waktu penghitungan mual muntah merupakan hal yang subyektif sehingga dalam pengkajiannya akan mengalami kesulitan. Responden akan diberikan pertanyan berapa menit jarak antara mual pertama dan berikutnya.

Penanganan Mual dan Muntah

Penanganan mual dan muntah dapat dilakukan dengan istirahat dan pemberian motivasi untuk asupan makanan yang mengandung karbohidrat serta rendah lemak dengan jumlah yang sedikit tetapi sering. Mual di trimester pertama kehamilan tidak memerlukan terapi obat.

Tanaman Jahe

Jahe merupakan rempah asli Indonesia yang sangat penting bagi kehidupan seharihari. Menurut Paimin (2009) Jahe sendiri berasal dari Asia Pasifik yang tersebar dari India sampai Cina. Kandungan kimia pada Jahe, yaitu: Volatile oil (minyak menguap) Biasanya disebut dengan minyak atsiri, minyak ini memrupakan komponen yang memberikan aroma khas pada jahe. Minyak ini tidak larut dalam air. Non-volatile oil (minyak tidak menguap) Nama lainnya yaitu minyak oleoresin.

Senyawa ini yang meberikan rasa pedas dan pahit. Menurut laporan penelitian di journal of Obsetri and Ginaekology. Maret 2005, dikatakan jahe memiliki khasiat untuk mengendurkan dan melemahkan otot pada saluran pencernaan sehingga akan mengurangi mual dan muntah. Pada penelitian ini kami akan menggunakan Vitamam 1 yang mengandung ekstrak jahe $200 \mathrm{mg}$ dan piridoksin $15 \mathrm{mg}$ produksi Novell Pharmaceutical Laboratories dengan dosis 1 kali sehari interval 24 jam, dimakan pagi hari atau sore hari.

\section{Piridoksin}

Vitamin B6 atau piridoksin terbentuk secara alami dalam makanan seperti daging, unggas, kacang-kacangan, bijibijian, pisang, dan alpukat. Sumber Vitamin B6 (Pyridoxine) Untuk memenuhi asupan vitamin B6 yang cukup, kita dapat secara alami memperolehnya denga cara mengkonsumsi beberapa jenis makanan seperti kacang-kacangan.

Fungsi Atau Manfaat Vitamin B6 akan memeberikan banyak manfaat. Vitamin ini juga dapat mengatasi penyakit kejang. Beberapa penyakit lain yang mungkin bisa di atasi dengan Vitamin B6 adalah Kanker paru-paru, sakit perut dan muntah pada masa kehamilan. Efek Samping penggunaan Priridoksin jangka panjang dengan dosis tinggi akan menimbulkan masalah otak dan saraf tertentu. Dosis yang dianjurkan adalah $3 x$ sehari dengan sebanyak $25 \mathrm{mg}$

\section{Metode Penelitian}

Jenis penelitian ini adalah eksperimental kuasi. Desain ini mempunyai variabel kasus dan variabel control. Pada penelitian ini variabel kasus dan control mempunyai pengaruh yang sama. Variabel kasus dalam penelitian ini yaitu subjek penelitian diberikan perlakuan ekstrak jahe dan piridoksin sedangkan untuk variabel control menggunakan piridoksin saja.

\section{Hasil Penelitian}

Penelitian berlangsung selama 3 bulan sejak 1 September 2016 sampai 28 November 2016 di Wilayah Puskesmas Kecamatan Baturraden . Berdasarkan perhitungan didapatkan sampel 58, tetapi dengan prediksi $10 \%$ tidak bisa mengikuti penelitian,. Selanjutnya dilakukan pengkajian terhadap 58 ibu dengan umur kehamilan 10 minggu yang memenuhi criteria penelitian. Kemudian ample yang ada dibagi menjadi kelompok kelola dan kelompok kontrol dilakukan dengan pembagian wilayah Puskesmas Baturaden 2 untuk kasus dan wilayah Puskesmas Baturaden 1 untuk kontrol.

Setelah dilakukan penelitain sampai akhir, ada 55 kasus yang dapat dilakukan lanjutan dikarenakan tiga kasus karena loss to follow up yaitu dua orang tidak dapat mengikuti penelitian karena pindah ke luar kota dan satu orang mengalami abortus imminens.

Dari 55 kasus yang diperoleh, peneliti membagi menajdi 28 kasus termasuk kedalam kelompok kelola (mendapat vitamam 1) dan 27 kasus termasuk kedalam kelompok kontrol (mendapat piridoksin). Berdasarkan pembagian tersebut, penelitian ini memenuhi persayaratan untuk dianalsiis lebih lanjut . 
Pada analisis univariat didapatkan deskripsi

Umur

\begin{tabular}{|l|l|l|}
\hline \multicolumn{1}{|c|}{ Umur } & Jumlah & Presentase \\
\hline $\begin{array}{l}<20 \text { Th dan } \\
>35\end{array}$ & 6 & $10.9 \%$ \\
\hline $\begin{array}{l}20 \text { Th s/d 35 } \\
\text { Th }\end{array}$ & 49 & $89.1 \%$ \\
\hline
\end{tabular}

Tabel. 1. frekuensi umur ibu hamil

Dari segi usia, terlihat bahwa usia subjek penelitian $89,1 \%$ pada usia reproduktif sedangkan $10,6 \%$ terjadi pada usia patologis yaitu $<20$ th atau $>35$ th.

Paritas

\begin{tabular}{|l|l|l|}
\hline \multicolumn{1}{|c|}{ Paritas } & Jumlah & Presentase \\
\hline Primipara & 30 & $54.5 \%$ \\
\hline Multipara & 25 & $45.5 \%$ \\
\hline
\end{tabular}

Tabel 2. Frekuensi Status Paritas Berdasarkan tabel diatas bahwa kejadian mual muntah terjadi pada $54,5 \%$ ibu primipara sedangkan $45,5 \%$ terjadi pada multipara.

Pendidikan

\begin{tabular}{|l|l|l|}
\hline Pendidikan & Jumlah & Presentase \\
\hline $\begin{array}{l}\text { Tidak } \\
\text { Sekolah }\end{array}$ & 2 & $3.6 \%$ \\
\hline SD & 9 & $16.4 \%$ \\
\hline SMP & 5 & $9.1 \%$ \\
\hline SMA/SMK & 34 & $61.8 \%$ \\
\hline Diploma & 3 & $5.5 \%$ \\
\hline Sarjana & 2 & $3.6 \%$ \\
\hline
\end{tabular}

Tabel. 3. Frekuensi Pendidikan Berdasarkan data diatas didapatkan hasil dari 55 responden, 3,6\% tidak tamat sekolah, $16,4 \%$ lulusan SD, $9,1 \%$ lulusan SMP, 61,8\% lulusan Diploma dan $3,6 \%$ lulusan sarjana.

Pekerjaan

\begin{tabular}{|l|l|l|}
\hline Pekerjaan & Jumlah & Presentase \\
\hline IRT & 47 & $85.5 \%$ \\
\hline PNS & 5 & $9.1 \%$ \\
\hline Wiraswasta & 3 & $5.5 \%$ \\
\hline
\end{tabular}

Tabel 4. Frekuensi Pekerjaan

Berdasarkan data diatas didapatkan bahwa responden yang mengalami mual muntah paling banyak dialami ibu rumah tangga sebanyak $85,5 \%$, untuk PNS $9,1 \%$ dan

Wiraswasta 5,5\%.

Pada Analisis bivariate pada penelitian ini melibatkan variabel kategorikal dan nominal baik untuk variabel independen dan dependen.
Hubungan antar variabel tersebut diuji dengan chi square.

Hari pertama saat pengkajian : Berdasarkan perhitungan chi-square test nilai signifikansi p-value sebesar 0.346 dan nilai chi-square sebesar 0.887 < chi square table

$(3,841)$. Karena nilai signifikansi $0.346>$ (0.05) atau che square hitung $0.887<3,841$ maka hipotesis nol dapat diterima yang artinya tidak ada hubungan antara Mual dengan Perlakuan

Pada hari ke tujuh hasil untuk chi-square test di atas dapat diketahui bahwa nilai signifikansi $p$-value sebesar 0.000 dan nilai chisquare sebesar $41,060>3,841$. Karena nilai signifikansi $0.000<(0.05)$ atau nilai chi square hitung $41,060>3,841$ maka hipotesis nol ditolak yang artinya ada hubungan antara perlakuan pemberian Vitamam dan piridoksin maupun piridoksin saja

.Berdasarkan hasil analisa diatas disimpulkan bahwa kombinasi ekstrak jahe dan piridoksin lebih efektif untuk menurunkan keluhan mual muntah pada ibu hamil

\section{Pembahasan}

Pada penelitian ini, peneliti memilih subjek penelitian dengan pertimbangan ibu hamil normal dengan menyingkirkan factor pengganggu diluar kehamilan, karena akan menimbulkan efek bias pada hasil penelitian. Pemilihan subjek penelitian pada ibu hamil 10 minggu dikarenakan pada usia ini otak ibu akan memproduksi hormone B-HCG pada usai 10-12 minggu mencapai puncaknya dan akan menghilang setelah 13 minggu.

Subjek penelitian dengan komplikasi kehamilan seperti abortus atau mual muntah hebat tidak diikutsertakan dalam penelitian ini dengan pertimbangan akan mempengaruhi hasil bias penelitian.

Adapaun factor lain yang mempengaruhi kevalidan penelitian ini seperti, faktor lingkungan, dan sosioekonomi. Pemilihan subjek penelitian kedalam kelompok kelola dan control menggunakan sesuai tempat. Berdasarkan usia, responden pada penelitian ini dalam kategori reproduksi sehat. berdasarkan paritas, terlihat bahwa perbandingan primi dan multi pada penelitian ini tidak jauh berbeda.

Beberapa penelitian memperlihatkan bahwa ibu hamil usia reproduktif dan primigravida kecenderungan melaporkan kejadian mual muntah lebih besar dibandingkan dengan 
multigravida . pada variable pendidikan, tampak bahwa pendidikan SMA lebih mendominasi. Sementara untuk variable dari pekerjan beragam mulai dari IRT, Wiraswasta , PNS.

Pendidikan dan pekerjaan memiliki pengaruh yang besar terhadap kejadian mual muntah pada ibu hamil, pada sebuah penelitian dikatakan bahawa pendidikan iu hamil setingkat/diatas SMA lebih cenderung mengalami mual muntah hal ini sejalan dengan ahsil penelitian yang menyatakan bahwa ibu hamil dengan riwayat pendidikan SMA tersebut ternyata ibu rumah tangga (IRT).

Sebuah penelitain memperlihatkan bahwa kejadian mual muntah pada ibu hamil lebih banyak terjadi pada ibu rumah tangga yang tidak melakukan aktiitas diluar rumah seperti pegawai . Tabel 3.7. memperlihatkan bahwa pada hari sebelum perlakuan tidak terdapat perbedaan bermakna $(p=0,346)$ antara skor Indeks Rhodes pada kedua kelompok penelitian, tetapi pada pengamatan hari ke-7 setelah perlakuan tampak perbedaan yang bermakna secara statistic $(p<0,005)$. Tidak didapatkannya perbedaan skor pada kelompok kelola dan control menunjukan bahwa kondisi sebelum perlakuan adalah sama 22 sedangkan pada kelompok kelola dan 22 dengan rentang nilai 18-24 pada kelompok kontrol $(?=0,739)$. Penilaian pada hari ke-7 setelah perlakuan, ternyata memperlihatkan perbedaan yang cukup signifikan. Pada pengukuran hasri ke 7 terdapat penurunan skor baik kelola maupun kontrol, tapi penurunan skor pada kelompok kelola mencapai $43,6 \%$, sementara pada kelompok kontrol $11,4 \%$ dan hal ini secara statistik bermakna $(p<0,001)$.

Penelitian yang lain juga menunjukan hasil yang sama, pada hari ke 7 pemberian ekstrak jahe terdapat penurunan skor, tetapi untuk pembanding menggunakan plasebo . penelitian ini dilakukan selama 7 hari berkaitan dengan mengurangi jumlah kasus loss to follow up atau drop out. Penelitian terdahulu juga menggunakan ekstrak jahe dengan dosis $1000 \mathrm{mg} /$ hari selama 4-7 hari.

Penggunaan ekstrak jahe untuk mengurangi mual muntah masih menajdi kontroversi walau hasil menunjukan terjadi penurunan mual muntah. Dosis yang aman untuk digunakan adalah $1000 \mathrm{mg} / \mathrm{hari}$, kombinasi ekstrak jahe dan piridoksin lebih efektif menurunkan keluhan mual dan muntah.
Hasil penelitian ini menunjukan bahwa kombinasi ekstrak jahe dan piridoksin kebih signifikan mengurangi keluhan mual muntah. Dengan kombinasi ekstrak jahe dan piridoksin akan meningkatkan efektifitas, akan mengurangi kematian janin. Pada penelitian kami mendapatkan kesimpulan bahwa kombinasi ekstrak jahe dan piridoksin ternyata memang lebih efekti menurunkan mual dan muntah dibandingkan piridoksin saja.

\section{Kesimpulan}

Kombiansi ekstrak ahe dan priridoksin lebih efektik mengurangi mual muntah pada ibu hamil dibandingkan dengan konsumsi piridoksin saja. Dosis yang dianjurkan untuk konsumsi ekstrak jahe dalams ehari adalah $700 \mathrm{mg}$ per hari. Dengan dikombinasi sediaan obat lain, komposisi ekstrak jahe dapat diperkecil sehingga mengurangi risiko terhadap kehamilan

\section{Saran}

Penelitian lanjutan dengan subjek lebih besar dan variable penelitian yang mengakomodir efek baik bagi ibu maupun janin.

\section{Ucapan Terima Kasih}

Terima kasih kepada Poltekkes Kemenkes Semarang yang memberikan dana penelitian serta Dinas Kesehatan Banyumas dan Puskesmas Baturaden yang turut serta membantu pelaksanaan penelitian.

\section{Daftar Pustaka}

Winkjosastro, H, 2002. Ilmu kebidanan. Jakarta :Yayasan Bina Pustaka Sarwono Prawiroharjo.

Saifuddin, A. B. 2001. Buku panduan praktis pelayanan kesehatan maternal dan neonatal.Jakarta :Yayasan Bina Pustaka sarwonoPrawirihardjo

Bryer E. A literature review of the effectiveness of ginger inalleviating mild-to-moderate nausea and vomiting of pregnancy. $J$ Midwifery Womens Health 2005;50(1):1-3.Backon J. Ginger in preventing nausea and vomiting in pregnancy; a caveat due to its thromboxane synthetase activity and 
effect on testosterone binding. Eur $\mathrm{J}$ Obstet Gynecol Reprod Biol 1991;42:163-4.

Fischer-Rasmussen W, Kjaer SK, Dahl C, Asping U. Ginger treatment of hyperemesis gravidarum. Eur J Obstet Gynecol Reprod Biol 1990;38:19 -24.

Vutyavanich T, Kraisarin T, Ruangsii R.

Ginger for nausea and vomiting in pregnancy: a randomized doublemasked, placebo-controlled trial. Obstet Gynecol 2001;97: 577-88.

Willetts KE, Ekangaki A, Eden JA. Effect of ginger extract on pregnancy induced nausea: a randomized controlled trial. Aust N Z J Obstet Gynaecol 2003;43:139-44.

Jewell MD, Young G. Interventions for nausea and vomiting in early pregnancy (Cochrane Review). In: The Cochrane Library, Issue 4, 2003. Chichester, UK: John Wiley \& Sons.

Ernst E, Pittler MH. Efficacy of ginger for nausea and vomiting: a syste matic review of randomized controlled trials [review]. Br J Anaesth 2000;84:36771.

Newall CA, Anderson LA, Phillipson JD. Herbal Medicines: a guide for health are professionals. London, UK: The Pharmaceutical Press; 1996.

Wilkinson JM. Effect of ginger tea on the fetal development of Sprague-Dawley rats. Reprod Toxicol 2000;14: 507-12 